\title{
Pengaruh Metode Outdoor Study Berbasis Subak Dalam Pembelajaran IPS Terhadap Sikap Sosial Dan Sikap Ekologis Siswa Sekolah Dasar Kecamatan Abiansemal Kabupaten Badung
}

\author{
Nengah Pariani ${ }^{1 *}$, I Putu Sriartha ${ }^{1}$, I Wayan Kertih $^{1}$ \\ 1Universitas Pendidikan Ganesha, Indonesia \\ *e-mail: nengahpariani16@gmail.com
}

Article history: Received 23 Juni 2021; Accepted 21 July 2021; Available online 31 August 2021

\begin{abstract}
Abstrak
Penelitian ini bertujuan untuk mengetahui pengaruh metode Outdoor Study berbasis subak dalam pembelajaran IPS terhadap sikap sosial dan sikap ekologis siswa kelas V sekolah dasar di gugus VIII kecamatan Abiansemal kabupaten Badung. Penelitian ini menggunakan jenis penelitian eksperimen semu/quasy eskperimental dengan rancangan posttest only control group design. Populasi dalam penelitian ini adalah seluruh siswa kelas V Sekolah Dasar di gugus VIII Kecamatan Abiansemal Kabupaten Badung yang berjumlah 199 orang siswa. Berdasarkan penelitian yang telah dilakukan disimpulkan bahwa: 1) terdapat pengaruh yang signifikan penerapan metode outdoor study berbasis subak dalam pembelajaran IPS terhadap sikap sosial siswa, 2) terdapat pengaruh yang signifikan penerapan metode outdoor study berbasis subak dalam pembelajaran IPS terhadap sikap ekologis siswa, dan 3) terdapat pengaruh yang signifikan penerapan metode outdoor study berbasis subak dalam pembelajaran IPS terhadap sikap sosial dan sikap ekologis siswa.
\end{abstract}

\begin{abstract}
This study aims to determine the influence of the subak-based Outdoor Study method in social science learning on the social attitudes and ecological attitudes of grade V elementary school students in cluster VIII Abiansemal subdistrict Badung district. This research uses a type of experimental research pseudo/quasi-experimental with posttest only control group design. The population in this study was all grade $\mathrm{V}$ elementary school students in cluster VIII Abiansemal District Badung regency, which amounted to 199 students. Based on the research that has been done, it is concluded that: 1) there is a significant influence of the application of subak-based outdoor study methods in social studies learning to students' social attitudes, 2) there is a significant influence of the application of subak-based outdoor study methods in social studies learning to students' ecological attitudes, and 3) there is a significant influence of the application of subak-based outdoor study methods in IPS learning on social attitudes and ecological attitudes of students.
\end{abstract}

\section{Pendahuluan}

Pembelajaran IPS di SD diharapkan dapat menjadi wahana bagi siswa untuk mempelajari diri sendiri dan lingkungan serta dapat menerapkannya di dalam kehidupan sehari-hari. Proses 
pembelajaran IPS menekankan pada pemberian pengalaman langsung untuk mengembangkan kompetensi agar siswa mampu menjelajahi dan memahami lingkungan sekitar dalam kehidupan sosial. Pembelajaran IPS diarahkan secara inkuiri sehingga membantu siswa untuk memperoleh pemahaman yang lebih mendalam tentang lingkungan sosial.

Pada pembelajaran IPS di SD gugus VIII kecamatan Abiansmal terlihat bahwa komunikasi siswa dalam mengikuti proses pembelajaran masih rendah, komunikasi yang rendah menyebabkan sikap sosial siswa rendah. Siswa cenderung pasif dalam mengikuti pembelajaran yang diberikan guru, sehingga interaksi dalam proses pembelajaran sangat minim terjadi. Salah satu penyebab sikap sosial rendah adalah ketergantungan siswa bermain gadget (HP), siswa terbiasa asik bermain sendiri, bahkan terkadang tidak menghiraukan apa yang terjadi di lingkungan sekitarnya. Hal ini berdampak siswa lebih merasa nyaman untuk menyendiri dalam mengerjakan apapun. Apabila hal ini terus dibiarkan maka tentunya sikap sosial siswa akan semakin menipis. Pernyataan ini diperkuat dari hasil penelitian yang dilakukan oleh Syahyudi (2019) dalam penelitiannya dinyatakan bahwa dampak negatif dari penggunaan gadget yang dialami oleh siswa berupa malas beraktifitas, kelelahan fisik, kecanduan yang mengakibatkan pengeluaran uang untuk membeli pulsa, konsentrasi belajar berkurang dan bentuk kenakalan lainnya. Dampak negatif yang paling tinggi adalah malasnya siswa beraktifitas sosial sebesar $81.81 \%$ dan berkurangnya daya konsentrasi siswa yang bahkan mencapai $100 \%$ dari total siswa pengguna gadget yang diberikan kuesioner tersebut. Hasil penelitian ini senada dengan hasil penelitian yang disampaikan oleh Witarsa, dkk (2018) yang menyatakan bahwa bermain gadget dengan durasi yang cukup panjang dan dilakukan setiap hari, bisa membuat anak berkembang ke arah pribadi yang antisosial.

Akibat dari menipisnya sikap sosial siswa, juga berdampak negatif terhadap kepercayaan diri yang dimiliki siswa, terutama kepercayaan diri yang berhubungan dengan berinteraksi dengan orang lain. Hal ini terbukti dari siswa belum mampu menumbuhkan kepercayaan diri secara mandiri pada saat pembelajaran. Hal ini diketahui ketika guru memberi kesempatan siswa untuk membentuk kelompok belajar. Siswa masih sulit untuk menentukan teman yang harus diajak dalam kelompoknya, sehingga kelompok dibentuk langsung oleh guru."Pada saat pembelajaran IPS siswa belum mampu mengaitkan konsep yang ada dalam materi pelajaran IPS dengan lingkungan yang ada disekitarnya. Seharusnya siswa dapat mengaitkan konsep dalam pembelajaran dengan lingkungan yang ada dalam kehidupan sehari-hari. Pernyataan ini sejalan dengan penelitian yang dilakukan oleh Muniroh, dkk (2018) dalam penelitiannya disimpulkan bahwa Terdapat pengaruh signifikan kepercayaan diri terhadap interaksi sosial siswa kelas X SMK Swasta Panca Bhkati Kubu Raya sebesar 98\%. Artinya, semakin tinggi keparcayaan diri siswa maka semakin baik pula interaksi sosial siswa, sebaliknya semakin rendah tingkat kepercayaan diri siswa, maka semakin rendah pula interaksi sosial siswa.

Rendahnya sikap sosial juga dapat dilihat dari sikap siswa selama masa pandemi tidak aktif bertanya dan berkomunikasi baik kepada guru maupun siswa lain (teman). Selain itu juga ketika sudah masuk masa new normal, siswa masih suka berdiam di rumah. Siswa tidak keluar ke taman atau alun-alun, atau tempat lain untuk menikmati lingkungan sebagai bentuk keseimbangannya dalam kehidupan sehari-harinya.

Menurut Ahmadi (2007:152) "sikap sosial adalah kesadaran individu yang menentukan perbuatan nyata dan berulang-ulang terhadap obyek sosial". Sikap sosial ini tidak dinyatakan oleh seorang tetapi diperhatikan oleh orang-orang sekelompoknya. Dalam proses pembelajaran, sikap sosial ini sangat penting harus dimiliki siswa. Hal itu dikarenakan pada hakekatnya siswa adalah mahkluk sosial yang tidak bisa hidup sendiri, tetapi harus saling bisa membantu antar individu dengan individu yang lain. Sikap sosial yang baik akan mempermudah siswa menguasai materi pembelajaran yang diberikan oleh guru baik di kelas maupun pembelajaran secara Daring (Dalam Jaringan). Hal ini dikarenakan apabila siswa mengalami permasalahan dalam belajar, siswa yang 
memiliki sikap sosial yang baik, tentunya akan bertanya dengan teman atau gurunya, sehingga permasalahan tersebut akan mendapatkan solusi yang terbaik.

Rendahnya sikap sosial siswa menyebabkan dampak negatif terhadap sikap ekologis siswa. Sikap ekologis adalah sikap peduli pada lingkungan. Menurut Goleman (2010: 38) mengemukakan bahwa sikap ekologis sebagai kemampuan/sikap manusia beradaptasi dalam ceruk ekologi tempat manusia berada. Sikap ekologis merupakan sebuah kemampuan atau kompetensi yang dimiliki peserta didik dalam merespon keadaan yang terjadi di sekitar lingkungannya dan mengaplikasikannya dalam kehidupannya sehari-hari. Permasalahan rendanya sikap ekologis siswa ini terjadi dikarenakan kurang berkembangnya interaksi siswa dalam kehidupan sehari-harinya, baik itu interaksi dengan sesama teman maupun dengan lingkungan disekitar. Padahal lingkungan sekitar merupakan hal yang sangat penting yang harus dijaga kelestariannya.

Berdasarkan hasil wawancara dengan beberapa guru SD gugus VIII kecamatan Abiansmal, dapat disampaikan hasil wawancara bahwa siswa kurang menyukai suasana pembelajaran yang selalu dilaksanakan di dalam kelas. Hal ini berdasarkan keterangan guru yang menjelaskan, bahwa siswa sering mengeluh kurang menyukai pembelajaran IPS, bahkan ada beberapa siswa yang menginginkan pelajaran dengan suasana di luar kelas, apalagi siswa belum pernah diajak untuk melaksanakan pembelajaran di luar kelas.

Salah satu upaya yang dapat dilakukan untuk mengatasi permasalahan di atas adalah dengan menerapkan metode outdoor study. Menurut Husamah $(2012,23)$ metode Outdoor study adalah metode dimana guru mengajak siswa belajar di luar kelas untuk melihat peristiwa langsung di lapangan dengan tujuan untuk mengakrabkan siswa dengan lingkungannya. Outdoor study dilakukan dengan memanfaatkan lingkungan sekolah sebagai sumber belajar. Peran guru di sini adalah sebagai motivator, artinya guru sebagai pemandu agar siswa belajar aktif, kreatif dan akrab dengan lingkungan. Metode outdoor study merupakan kegiatan pembelajaran dimana siswa akan dihadapkan pada realita, siswa tidak hanya belajar dengan menerima apa yang diberikan guru saja, melainkan juga dapat melakukan aktivitas belajar seperti pengamatan, diskusi, dan observasi langsung di lapangan. Hal ini didukung oleh kondisi lingkungan di sekitar SD kecamatan Abiansemal yang dapat menunjang sebagai kegiatan belajar IPS."

"Dilihat dari sisi lingkungan, lingkungan sekitar menyediakan fenomena alam dan kegiatan sosial yang menarik namun belum dimanfaatkan dengan optimal dalam pembelajaran IPS. Siswa memerlukan ilmu yang bersifat konkret untuk menjawab rasa keingintahuannya yang tinggi, dan memotivasinya untuk melahirkan pertanyaan terhadap objek dan peristiwa yang terjadi di lingkungan. Dengan demikian, siswa mampu mencari dan menemukan sendiri rasa keingintahuan dalam objek pembelajaran yang bersifat konkret salah satunya menggunakan metode pembelajaran di luar kelas yang disebut metode outdoor study, sehingga siswa mampu mencari dan menemukan sendiri rasa keingintahuannya."

"Metode outdoor study dipilih karena pada hakikatnya belajar merupakan interaksi antara individu dengan lingkungannya. Siswa secara aktif dapat terlibat dalam proses pembelajaran, sehingga pembelajaran IPS menarik bagi siswa untuk dipelajari. Pembelajaran outdoor selain untuk peningkatan kemampuan juga lebih bersifat untuk peningkatan aspek-aspek psikologi siswa, seperti rasa senang dan rasa kebersamaan yang selanjutnya berdampak terhadap peningkatan sikap sosial siswa (Afandi, dkk, 2013)."

Dalam penelitian ini metode outdoor study dilaksanakan berbasis subak. Cantika (1985) menyatakan bahwa subak merupakan organisasi tradisional yang mampu mengelola air irigasi dari empelan yaitu suatu bangunan dengan pengambilan air di sungai yang dibangun oleh subak secara swadaya, sampai ke petak sawahnya. Keunggulan subak sebagai suatu sistem irigasi yang dikelola petani secara swadaya untuk semusim, khususnya padi, telah 
banyak diulas dalam berbagai tulisan. Subak tidak hanya terbatas pada organisasi pengelolaan air dan jaringan irigasi, namun berkaitan erat pada produksi pangan, ekosistem lahan sawah beririgasi, dan ritual keagamaan yang terkait dengan budidaya padi. Oleh karena itu subak dikatakan memiliki banyak manfaat (Sutawan, 1983). Pemilihan metode outdoor study berbasis subak dikarenakan lokasi penelitian ini dekat dengan areal pertanian. Selain itu, bertujuan untuk memperkenalkan budaya local kepada siswa semenjak dini.

Berdasarkan pemaparan di atas, maka pada penelitian ini akan mengambil judul tentang Pengaruh Metode Outdoor Study Berbasis Subak Dalam Pembelajaran IPS Terhadap Sikap Sosial dan Sikap Ekologis Siswa Kelas V Sekolah Dasar di Gugus VIII Kecamatan Abiansemal Kabupaten Badung. Tujuan dari diadakannya penelitian ini adalah sebagai berikut, 1) Untuk mengetahui pengaruh penerapan metode outdoor study berbasis subak dalam pembelajaran IPS terhadap sikap sosial siswa kelas V Sekolah Dasar di gugus VIII Kecamatan Abiansemal, 2) Untuk mengetahui pengaruh penerapan metode outdoor study berbasis subak dalam pembelajaran IPS terhadap sikap ekologis siswa kelas V Sekolah Dasar di gugus VIII Kecamatan Abiansemal, 3) Untuk mengetahui pengaruh penerapan metode outdoor study berbasis subak dalam pembelajaran IPS terhadap sikap sosial dan sikap ekologis siswa kelas V Sekolah Dasar di gugus VIII Kecamatan Abiansemal.

\section{Metode}

Secara operasional, metode Outdoor Study adalah metode dimana guru mengajak siswa belajar di luar kelas untuk melihat peristiwa langsung di lapangan dengan tujuan untuk mengakrabkan siswa dengan lingkungannya. Outdoor Study dilakukan dengan memanfaatkan lingkungan sekolah sebagai sumber belajar. Peran guru di sini adalah sebagai motivator, artinya guru sebagai pemandu agar siswa belajar aktif, kreatif dan akrab dengan lingkungan. Sikap sosial merupakan sikap individu dalam berinteraksi dengan lingkungan di sekitar yang berpedoman pada nilai-nilai keharmonisan yang ada di masyarakat. Secara operasional, sikap sosial adalah skor yang didapatkan siswa setelah mengisi kuesioner sikap sosial yang diberikan oleh guru. Kuesioner yang dibuat menggunakan skala likert 1-5, sehingga data yang terkumpul bersifat interval. Dalam membuat kuesioner sikap sosial, pada penelitian ini menggunakan indikator yang dikemukakan yang ada pada kurikulum 2013 yakni: 1) jujur, 2) Disiplin, 3) Tanggung jawab, 4) Santun, 5) Peduli, dan 6) Percaya diri. Sikap ekologis adalah sikap yang peduli lingkungan yang dilakukan individu dalam berinteraksi dengan lingkungan sekitar. Secara operasional, sikap ekologis adalah skor yang didapatkan siswa setelah mengisi kuesioner sikap ekologis yang diberikan oleh guru. Kuesioner yang dibuat menggunakan skala likert 1-5, sehingga data yang terkumpul bersifat interval. Dalam membuat kuesioner sikap ekologis, pada penelitian ini menggunakan indikator: 1) Menghormati keberadaan alam (tanah, air, tumbuhan, udara), 2) Bertanggungjawab terhadap pemanfaatan sumber daya alam, 3) Melestarikan/tidak merusak alam, 4) Peduli terhadap bencana alam, dan 5) Beradaptasi dengan alam.

Penelitian ini menggunakan jenis penelitian eksperimen semu/quasy eskperimental, karena menggunakan unit kelas sebagai kelompok control dan kelompok eksperimen di mana kelas sulit dilakukan randomisasi. Rancangan eksperimen semu yang digunakan adalah posttest only control group design.

Populasi dalam penelitian ini adalah seluruh siswa kelas V Sekolah Dasar di gugus VIII Kecamatan Abiansemal Kabupaten Badung yang berjumlah 199 orang siswa. Teknik pengambilan sampel pada penelitian ini menggunakan teknik random sampling. Sebelum random sampling dilakukan, terlebih dahulu dilakukan uji kesetaraan kelas. Berdasarkan uji kesetaraan yang telah dilakukan, didapatkan bahwa seluruh kelas di gugus VIII Kecamatan Abiansemal Kabupaten Badung memiliki kemampuan yang setara. Maka dari itu, selanjutnya dilakukan pengundian untuk menentukan kelas eksperimen dan kelas kontrol. Berdasarkan pengundian yang telah 
dilakukan, didapatkan hasil bahwa SD No 2 Sibangkaja sebagai kelompok kontrol dengan jumlah siswa 38 orang, sedangkan SD No 4 Sibanggede sebagai kelompok eksperimen dengan jumlah siswa 38 orang.

Dalam penelitian ini menggunakan satu variabel bebas dan dua variabel terikat. Variabel bebas dalam penelitian ini adalah metode Outdoor study. Sedangkan variabel terikat dalam penelitian ini adalah sikap sosial dan sikap ekologis siswa. Data yang dikaji pada penelitian ini adalah data tentang sikap sosial dan sikap ekologis siswa dalam pembelajaran. Data sikap sosial dan sikap ekologis siswa dikumpulkan metode kuesioner. Setelah data terkumpul, selanjutnya dilanjutkan dengan analisis data secara deskriptif, pengujian prasyarat analisis dan pengujian hipotesis. Adapun analisis yang digunakan untuk pengujian hipotesis adalah Manova.

Hipotesis yang diuji pada penelitian ini adalah sebagai berikut 1) Terdapat pengaruh yang signifikan penerapan metode outdoor study berbasis subak dalam pembelajaran IPS terhadap sikap sosial siswa kelas V Sekolah Dasar di gugus VIII Kecamatan Abiansemal, 2) Terdapat pengaruh yang signifikan penerapan metode outdoor study berbasis subak dalam pembelajaran IPS terhadap sikap ekologis siswa kelas V Sekolah Dasar di gugus VIII Kecamatan Abiansemal, 3) Terdapat pengaruh yang signifikan penerapan metode outdoor study berbasis subak dalam pembelajaran IPS terhadap sikap sosial dan sikap ekologis siswa kelas V Sekolah Dasar di gugus VIII Kecamatan Abiansemal.

\section{Hasil dan Pembahasan}

Data yang diperoleh dalam penelitian adalah data tentang sikap sosial dan sikap ekologis dari kelompok siswa yang mengikuti pembelajaran metode outdoor study berbasis subak dan kelompok yang mengikuti pembelajaran konvensional. Rincian deskripsi data pada penelitian ini secara umum seperti terlihat pada Tabel 1.

Tabel 1. Rekapitulasi Deskripsi Data Hasil Penelitian

\begin{tabular}{|l|c|c|c|c|}
\hline Statistik & Data & A2Y1 & A1Y2 & A2Y2 \\
\hline Mean & 136 & 131,26 & 118,84 & 113,39 \\
\hline Median & 136 & 132 & 119,5 & 114 \\
\hline Modus & 132 & 132 & 118 & 109 \\
\hline Standar Deviasi & 4,36 & 5,14 & 4,68 & 4,97 \\
\hline Varians & 19,03 & 26,47 & 21,87 & 24,73 \\
\hline Range & 20 & 19 & 21 & 18 \\
\hline Skor Minimum & 128 & 122 & 107 & 105 \\
\hline Skor Maksimum & 148 & 141 & 128 & 123 \\
\hline Jumlah & 5168 & 4988 & 4516 & 4309 \\
\hline
\end{tabular}

Keterangan

A1Y1 : Deskripsi data sikap sosial siswa yang mengikuti pembelajaran metode outdoor study berbasis subak

A2Y1 : Deskripsi data sikap sosial siswa yang mengikuti pembelajaran konvensional

A1Y2 : Deskripsi data sikap ekologis siswa yang mengikuti pembelajaran metode outdoor study berbasis subak

A2Y2 : Deskripsi data sikap ekologis siswa yang mengikuti pembelajaran konvensional 
Berdasarkan Tabel 1 diatas dapat dideskripsikan data tentang sikap sosial yang mengikuti pembelajaran metode outdoor study berbasis subak mempunyai rentangan $=20, n=38$, skor minimum $=128$, skor maksimum $=148$, rata-rata $=136$, median $=136$, odus $=132$, standar deviasi $=4,36$, dan varians $=19,03$. Kencederungan data sikap sosial siswa yang mengikuti pembelajaran metode outdoor study berbasis subak masuk dalam kategori sangat tinggi.

Data tentang sikap sosial siswa yang mengikuti pembelajaran konvensional mempunyai rentangan $=21, \mathrm{n}=38$, skor minimum $=107$, skor maksimum $=128$, rata-rata $=118,84$, median $=$ 119,5 , modus $=118$, standar deviasi $=4,68$, dan varians $=21,87$. Kencederungan data sikap sosial siswa yang mengikuti pembelajaran konvensional masuk dalam kategori tinggi.

Data tentang sikap ekologis yang mengikuti pembelajaran metode outdoor study berbasis subak mempunyai rentangan $=19, \mathrm{n}=38$, skor minimum $=122$, skor maksimum $=141$, rata-rata $=131,26$, median $=132$, modus $=132$, standar deviasi $=4,36$, dan varians $=26,47$. Kencederungan data data sikap ekologis siswa yang mengikuti pembelajaran metode outdoor study berbasis subak masuk dalam kategori sangat tinggi.

Data tentang sikap ekologis yang mengikuti pembelajaran konvensional mempunyai rentangan $=18, \mathrm{n}=38$, skor minimum $=105$, skor maksimum $=123$, rata-rata $=113,39$, median $=114$, modus $=109$, standar deviasi $=4,97$, dan varians $=24,73$. Kencederungan data sikap ekologissiswa yang mengikuti pembelajaran konvensional masuk dalam kategori tinggi.

Setelah data selesai dideskripsikan, selanjutnya dilanjutkan ke dalam uji prasyarat analisis. Berdasarkan uji prasyarat analisis yang telah dilakukan, didapatkan hasil sebagai berikut. Pengujian normalitas sebaran data mendapatkan hasil bahwa seluruh kelompok data mendapatkan nilai signifikansi di atas 0,05, sehingga dapat disimpulkan bahwa seluruh kelompok data pada penelitian ini berdistribusi normal. Berdasarkan uji homogenitas yang telah dilakukan, didapatkan nilai signifikansi secara bersama-sama maupun secara terpisah di atas 0,05, sehingga dapat disimpulkan bahwa seluruh kelompok data homogen.

Sedangkan pengujian korelasi antar variabel terikat yang telah dilakukan menghasilkan rhitung yang bernilai 0,153 dan 0,194 memiliki nilai signifikansi sebesar 0,359 dan 0,244 atau lebih besar dari 0,05 (sig.>0,05). Ini menunjukan hubungan atau korelasi antar variable terikat tidak signifikan atau bahwa tidak ada korelasi antar variable terikat. Maka dari itu, uji MANOVA layak untuk dilakukan. Berdasarkan pengujian hipotesis menggunakan MANOVA, ditemukan beberapa hal sebagai berikut. Hasil pengujian hipotesis pertama disimpulkan bahwa terdapat pengaruh yang signifikan penerapan metode outdoor study berbasis subak dalam pembelajaran IPS terhadap sikap sosial siswa kelas V Sekolah Dasar di gugus VIII Kecamatan Abiansemal, dengan $\mathrm{F}$ hitung sebesar 273.564 dan signifikansi sebesar 0,000.

Hasil pengujian hipotesis kedua disimpulkan bahwa terdapat pengaruh yang signifikan penerapan metode outdoor study berbasis subak dalam pembelajaran IPS terhadap sikap ekologis siswa kelas V Sekolah Dasar di gugus VIII Kecamatan Abiansemal, dengan F hitung sebesar 236.960 dan signifikansi sebesar 0,000. Hasil pengujian hipotesis ketiga disimpulkan bahwa terdapat pengaruh yang signifikan penerapan metode outdoor study berbasis subak dalam pembelajaran IPS terhadap sikap sosial dan sikap ekologis siswa kelas V Sekolah Dasar di gugus VIII Kecamatan Abiansemal, dengan F hitung sebesar 304.533 dan signifikansi sebesar 0,000.

Terdapat Pengaruh yang Signifikan Penerapan Metode Outdoor Study Berbasis Subak Dalam Pembelajaran IPS Terhadap Sikap Sosial Siswa Kelas V Sekolah Dasar di Gugus VIII Kecamatan Abiansemal Berdasarkan pengujian hipotesis pertama, disimpulkan bahwa terdapat pengaruh yang signifikan penerapan metode outdoor study berbasis subak dalam pembelajaran IPS terhadap sikap sosial siswa kelas V Sekolah Dasar di gugus VIII Kecamatan Abiansemal. Apabila dilihat dari rata-rata sikap sosial siswa, rata-rata sikap sosial siswa yang mengikuti 
pembelajaran metode outdoor study berbasis subak mendapatkan rata-rata sebesar 136, sedangkan rata-rata sikap sosial siswa yang mengikuti pembelajaran metode konvensional sebesar 131,26. Hasil ini menunjukkan sikap sosial siswa yang mengikuti pembelajaran metode outdoor study berbasis subak lebih baik daripada siswa yang mengikuti metode konvensional. Perbandingan rata-rata sikap sosial siswa yang mengikuti pembelajaran metode outdoor study berbasis subak dengan siswa yang mengikuti metode konvensional dapat dilihat pada histogram berikut.

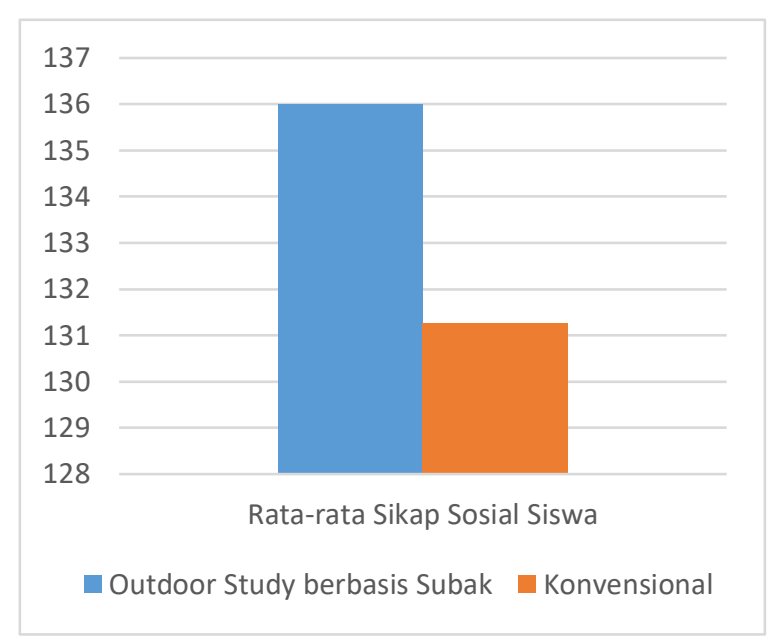

Gambar 1. Histogram Perbandingan Sikap Sosial Siswa

Hasil penelitian ini diperkuat dari hasil penelitian yang dilakukan Amalia, dkk (2018) dengan judul Pengaruh Metode Pembelajaran Outdoor Learning Terhadap Motivasi Dan Hasil Belajar Peserta Didik Kelas VII SMP Negeri 15 Makassar (Studi Pada Materi Pokok Interaksi Makhluk Hidup Dengan Lingkungan). Berdasarkan hasil penelitian dapat disimpulkan bahwa motivasi kelas eksperimen lebih tinggi dari motivasi kelas kontrol. Selanjutnya, N-gain hasil belajar peserta didik untuk kriteria tinggi mencapai 56,67\% persentasenya pada kelas eksperimen sedangkan pada kelas kontrol persentasenya hanya sebesar 20,00\%. Kriteria tinggi pada kategori N-gain tersebut menunjukkan bahwa terjadi peningkatan hasil belajar yang lebih signifikan pada kelas eksperimen yang diajar menggunakan metode outdoor learning dibandingkan dengan kelas kontrol yang diajar tanpa menggunakan metode outdoor learning.

Selanjutnya penelitian yang dilakukan oleh Taqwan (2019) dengan judul Pengaruh Pembelajaran Luar Kelas (Outdoor Learning) Terhadap Kemampuan Pemecahan Masalah Siswa Kelas VII SMP Negeri 05 Seluma. hasil Penelitian menunjukkan bahwa Terdapat pengaruh Pembelajaran Luar Kelas (pembelajaran terbuka) dan gaya belajar terhadap kemampuan pemecahan masalah siswa SMP negeri 05 Seluma. Besar pengaruh Pembelajaran Luar Kelas (luar ruangan belajar) Dan gaya belajar Terhadap kemampuan Pemecahan Masalah 97,3\%.

Penelitian yang dilakukan oleh Devi dan Rafvesa (2018) dengan judul Efektivitas Metode Outdoor Study Dengan Musik Klasik Terhadap Kemampuan Menganalisis Unsur Puisi. Dalam penelitiannya dapat disimpulkan bahwa penggunaan metode Outdoor Study dengan musik klasik terhadap kemampuan menganalisis unsur puisi siswa lebih baik dibandingkan dengan tidak menggunakan metode Outdoor Study dengan musik klasik.

Sikap sosial adalah kesadaran individu yang menentukan perbuatan nyata dan berulangulang terhadap obyek sosial". Sikap sosial ini tidak dinyatakan oleh seorang tetapi diperhatikan oleh orang-orang sekelompoknya (Ahmadi, 2007:152). Sikap sosial oleh Permendikbud No. 21 tahun 2016 tentang Standar Isi didefinisikan sebagai suatu sikap yang menunjukan perilaku jujur, 
disiplin, santun, percaya diri, peduli, dan bertanggung jawab dalam berinteraksi dengan keluarga, teman, guru, tetangga, dan Negara. Sikap sosial siswa dapat dipupuk semenjak dini dengan menerapkan metode outdoor study berbasis subak kepada siswa.

Menurut Sudjana \& Rivai (2010) kelebihan outdoor study ada enam, yakni (1) meningkatkan kapasitas belajar siswa, (2) mengungkap fakta dan memperoleh data di lapangan, (3) mendorong sikap sosial siswa, (4) mengembangkan kemampuan fisik-sosial, (5) menjadikan belajar siswa bermakna, dan (6) metode cocok diterapkan pada mata pelajaran Geografi.

Masyarakat Bali memiliki berbagai keunikan pada budaya lokalnya, salah satunya disebut sistem subak. Subak pada dasarnya adalah organisasi atau perkumpulan petani yang mengelola air irigasi dan sistem tanam berdasarkan filosofi Tri Hita Karana (Sriartha dan Kertih, 2019). Sistem subak mengacu pada organisasi petani komunal tradisional yang mengelola dan mengontrol air irigasi dan mekanisme penanaman tanaman berdasarkan filosofi Tri Hita Karana (THK). Sistem subak telah ditetapkan oleh UNESCO sebagai warisan budaya dunia atas penilaiannya bahwa subak lahir dari budaya masyarakat Bali berdasarkan konsep Tri Hita Karana (THK) termasuk kearifan lokal yang terbukti mencerminkan keaslian nilai-nilai universal yang luar biasa, salah satunya adalah nilai yang kuat sebagai perekat antara para konservasionis sosial dan ekologi (Sriartha dkk, 2017).

Metode outdoor study berbasis subak merupakan sebuah inovasi pembelajaran yang mampu membangkitkan semangat siswa dalam belajar. Siswa merasa belajar sambil menikmati keindahan alam yang ada di lingkungan sekitarnya. Hal ini membuat proses pembelajaran IPS yang diikuti oleh siswa menjadi lebih bermakna dan berkesan bagi siswa. Dengan bersemangatnya siswa dalam belajar, menyebabkan siswa saling menunjukkan kemampuan yang dimilikinya, namun juga siswa tidak mengesampingkan sikap saling membantu dengan temantemannya. Dalam proses pembelajaran metode outdoor study berbasis subak, siswa terlihat saling membantu dan bekerjasama dengan teman-temannya dalam memecahkan pertanyaan atau permasalahan yang diberikan oleh guru. Terlihat siswa sangat antusias dalam belajar, apalagi banyak hal-hal baru yang didapatkan siswa saat diajak langsung ke sawah. Berdasarkan pemaparan di atas, dapat disimpulkan bahwa terdapat pengaruh yang signifikan penerapan metode outdoor study berbasis subak dalam pembelajaran IPS terhadap sikap sosial siswa kelas V Sekolah Dasar di gugus VIII Kecamatan Abiansemal.

Terdapat Pengaruh yang Signifikan Penerapan Metode Outdoor study Berbasis Subak Dalam Pembelajaran IPS Terhadap Sikap Ekologis Siswa Kelas V Sekolah Dasar di Gugus VIII Kecamatan Abiansemal. Berdasarkan pengujian hipotesis kedua disimpulkan bahwa terdapat pengaruh yang signifikan penerapan metode outdoor study berbasis subak dalam pembelajaran IPS terhadap sikap ekologis siswa kelas V Sekolah Dasar di gugus VIII Kecamatan Abiansemal.

Apabila dilihat dari rata-rata sikap ekologis siswa, rata-rata sikap ekologis siswa yang mengikuti pembelajaran metode outdoor study berbasis subak mendapatkan rata-rata sebesar 118,84, sedangkan rata-rata sikap ekologis siswa yang mengikuti pembelajaran metode konvensional sebesar 113,39. Hasil ini menunjukkan sikap ekologis siswa yang mengikuti pembelajaran metode outdoor study berbasis subak lebih baik daripada siswa yang mengikuti metode konvensional. Perbandingan rata-rata sikap ekologis siswa yang mengikuti pembelajaran metode outdoor study berbasis subak

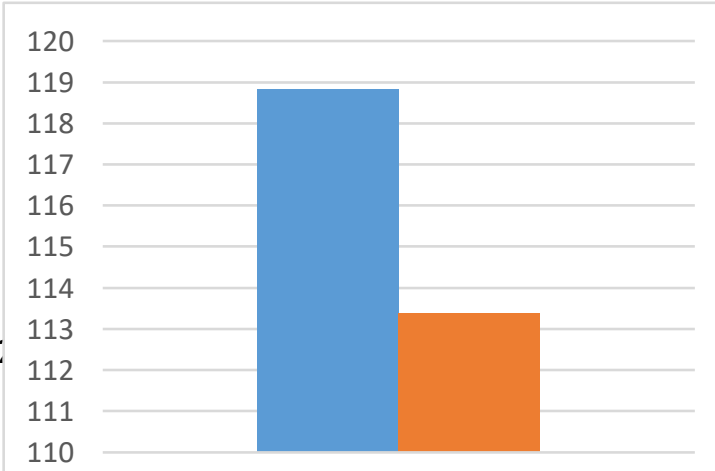


Gambar 2. Histogram Perbandingan Sikap Ekologis Siswa

Hasil penelitian ini diperkuat dengan hasil penelitian yang dilakukan oleh Kurnianti, dkk (2020) dengan judul Implementasi Metode Outdoor study Dalam Pembelajaran Ilmu Pengetahuan Alam Pada Hasil dan Motivasi Belajar Siswa Kelas IV SD Negeri Gedanganak 02 Ungaran. Hasil penelitian ini menunjukkan bahwa metode outdoor study terbukti efektif terhadap kemampuan hasil dan motivasi belajar siswa kelas IV SD Negeri Gedanganak 02 Ungaran dengan diperoleh nilai rata-rata pretest 60,2 dan pada posttest memperoleh nilai rata-rata 75,6. Uji t yang diperoleh thitung > ttabel yaitu 10,282 > 2,064 maka Ha diterima. Selanjutnya penelitian yang dilakukan oleh Sejati (2016) dengan judul Pengaruh Metode Pembelajaran Outdoor Study Terhadap Kemampuan Menulis Karya Ilmiah Geografi SMA. Dalam penelitiannya disimpulkan bahwa ada pengaruh metode pembelajaran Outdoor Study terhadap kemampuan menulis karya ilmiah Geografi SMA.

Penelitian yang dilakukan oleh Cintami dan Mukminan (2018) dengan judul efektivitas Outdoor Study untuk meningkatkan hasil belajar Geografi berdasarkan locus of control di sekolah menengah atas Kota Palembang. Hasil penelitian ini menunjukkan: 1) terdapat interaksi antara metode pembelajaran dan locus of control terhadap hasil belajar kognitif sehingga outdoor study lebih efektif untuk peserta didik bertipe extrovert dan Outdoor Study tidak efektif untuk peserta didik bertipe introvert, dan 2) terdapat interaksi antara metode pembelajaran dan locus of control terhadap sikap peduli lingkungan sehingga Outdoor Study lebih efektif untuk peserta didik bertipe extrovert dan Outdoor Study tidak efektif untuk peserta didik bertipe introvert.

Penerapan metode outdoor study berbasis subak dalam pembelajaran IPS sangat cocok diterapkan untuk meningkatkan sikap ekologis siswa. Dengan diajaknya siswa untuk terjun langsung ke lapangan dan melihat langsung situasi yang ada di sekitar alam mereka terutama subak, mereka merasa senang dan bangga memiliki warisan budaya dari leluhur mereka. Dalam proses pembelajaran IPS dengan penerapan metode outdoor study berbasis subak ini, siswa diberikan pemahaman bahwa apabila mereka menginginkan alam/warisan budaya ini tetap lestari, mereka harus dapat menjaga, melestarikan, dan memanfaatkan sesuai dengan kebutuhan mereka.

Supriatna (2016: 87-88) mengemukakan bahwa sikap ekologis sangat penting dikembangkan dalam proses pembelajaran karena para lulusan sekolah akan berperan sebagai: 1) agent of change di masyarakat, yaitu agen dalam mengembangkan perilaku masyarakat yang memiliki pengetahuan, wawasan, sikap dan perilaku yang menjunjung tinggi kesinambungan atau keberlanjutan (sustainability), 2) agen yang sadar dengan keterbatasan sumber daya alam dan adanya isu global warming dan 3) agen yang bisa menerapkan kecerdasan ekologis atau aplikasi pembelajaran yang bersifat ekopedagosis dalam kehidupan. Keberlangsungan kehidupan manusia pada masa yang akan datang akan tergantung pada kecerdasan ekologis. Agar peserta didik memiliki kecerdasan ekologis, maka diperlukan sebuah kompetensi yang menjadi indikator tercapainya penanaman pemahaman kecerdasan ekologis pada peserta didik. Sedangkan menurut Palmer \& Neal (1994: 21-27) menjelaskan bahwa kompetensi ekologis dalam dunia pendidikan dapat dicapai dengan mengembangkan kepekaan, kesadaran, pemahaman, pemikiran 
kritis, dan memecahkan masalah yang berhubungan dengan permasalahan lingkungan hidup serta pembentukan etika lingkungan. Berdasarkan pemaparan di atas, dapat disimpulkan bahwa terdapat pengaruh yang signifikan penerapan metode outdoor study berbasis subak dalam pembelajaran IPS terhadap sikap ekologis siswa kelas V Sekolah Dasar di gugus VIII Kecamatan Abiansemal.

Terdapat Pengaruh yang Signifikan Penerapan Metode Outdoor study Berbasis Subak Dalam Pembelajaran IPS Terhadap Sikap Sosial dan Sikap Ekologis Siswa Kelas V Sekolah Dasar di Gugus VIII Kecamatan Abiansemal. Berdasarkan pengujian hipotesis ketiga disimpulkan bahwa terdapat pengaruh yang signifikan penerapan metode outdoor study berbasis subak dalam pembelajaran IPS terhadap sikap sosial dan sikap ekologis siswa kelas V Sekolah Dasar di gugus VIII Kecamatan Abiansemal.

Menurut Husamah $(2012,23)$ metode Outdoor study adalah metode dimana guru mengajak siswa belajar di luar kelas untuk melihat peristiwa langsung di lapangan dengan tujuan untuk mengakrabkan siswa dengan lingkungannya. Outdoor study dilakukan dengan memanfaatkan lingkungan sekolah sebagai sumber belajar. Peran guru di sini adalah sebagai motivator, artinya guru sebagai pemandu agar siswa belajar aktif, kreatif dan akrab dengan lingkungan. Sedangkan menurut Rustam dan Apik (2015) menyatakan bahwa Metode outdoor study atau metode pembelajaran di luar ruangan kelas merupakan metode pembelajaran yang mampu memupuk kreatifitas, inisiatif, kerjasama atau gotong royong dan mengakrapkan peserta didik dengan lingkungan sekitarnya. Peran guru pada pembelajaran outdoor study adalah sebagai motivator, artinya guru sebagai pemandu agar peserta didik belajar secara aktif, efektif dan akrab dengan lingkungan.

Penerapan metode outdoor study berbasis subak sangat efektif diterapkan dalam pembelajaran IPS teruatama dalam meningkatkan sikap sosial dan sikap ekologis siswa. Sikap sosial merupakan sikap yang ada dalam kontrol masyarakat. Interaksi yang ada di masyarakat merupakan interaksi yang menjaga hubungan antar individu agar saling menerapkan normanorma positif yang berada di masyarakat. Sedangkan sikap ekologis merupakan seperangkat nilai-nilai dan sikap peduli terhadap lingkungan hidup serta memotivasi untuk berpartisipasi secara aktif dalam memperbaiki dan melindungi lingkungan hidup.

Dalam pembelajaran IPS yang menerapkan metode outdoor study berbasis subak siswa diajak langsung untuk memahami lingkungan alam mereka. Siswa diberikan kesempatan untuk memaknai dan saling bertukar informasi tentang segala pemahaman awal yang dimilikinya. Selanjutnya, beranjak dari pemahaman awal siswa, guru memberikan berbagai macam pertanyaan dan tugas kepada siswa untuk dikerjakan secara bersama-sama. Hal ini tentunya membuat siswa harus bekerjasama dan bergotongroyong dalam menyelesaikan tugas yang diberikan oleh guru.

Metode pembelajaran seperti ini memberikan banyak manfaat bagi siswa, selain siswa belajar untuk menguasai materi pembelajaran yang harus dikuasainya, siswa juga mendapatkan pemahaman akan pentingnya mereka untuk menjaga lingkungan di sekitarnya. Berdasarkan hal tersebut, maka dapat disimpulkan bahwa terdapat pengaruh yang signifikan penerapan metode outdoor study berbasis subak dalam pembelajaran IPS terhadap sikap sosial dan sikap ekologis siswa kelas V Sekolah Dasar di gugus VIII Kecamatan Abiansemal.

Temuan penelitian ini memiliki implikasi penelitian, sebagai berikut, 1) Penerapan pembelajaran metode outdoor study berbasis subak dapat memperbaiki proses pembelajaran. Guru dalam pembelajaran metode outdoor study berbasis subak adalah sebagai fasilitator yang mendorong siswa untuk belajar secara kritis, dalam aspek budaya dan kehidupan sosial siswa sehingga dapat meningkatkan sikap sosial dan sikap ekologis siswa, 2) Implementasi pembelajaran metode outdoor study berbasis subak dapat memberikan bantuan kepada siswa 
untuk memahami, menjaga warisan budaya serta mencintai lingkungan yang ada di sekitar mereka.

\section{Simpulan dan Saran}

Berdasarkan penelitian yang telah dilakukan, dapat disimpulkan sebagai berikut. Terdapat pengaruh yang signifikan penerapan metode outdoor study berbasis subak dalam pembelajaran IPS terhadap sikap sosial siswa kelas V Sekolah Dasar di gugus VIII Kecamatan Abiansemal, dengan $\mathrm{F}$ hitung sebesar 273.564 dan signifikansi sebesar 0,000. Terdapat pengaruh yang signifikan penerapan metode outdoor study berbasis subak dalam pembelajaran IPS terhadap sikap ekologis siswa kelas V Sekolah Dasar di gugus VIII Kecamatan Abiansemal, dengan F hitung sebesar 236.960 dan signifikansi sebesar 0,000. Terdapat pengaruh yang signifikan penerapan metode outdoor study berbasis subak dalam pembelajaran IPS terhadap sikap sosial dan sikap ekologis siswa kelas V Sekolah Dasar di gugus VIII Kecamatan Abiansemal, dengan F hitung sebesar 304.533 dan signifikansi sebesar 0,000.

Berdasarkan penelitian yang telah dilakukan, dapat disampaikan beberapa saran sebagai berikut. Siswa disarankan untuk mengembangkan sikap sosial dan sikap ekologis yang mereka miliki. Hal ini dikarenakan mereka merupakan sebagai generasi penerus yang memiliki kewajiban untuk menjaga dan mencintai lingkungan yang ada di sekitar mereka. Guru disarankan untuk selalu melakukan inovasi-inovasi pembelajaran yang tidak hanya mementingkan aspek kognitif siswa saja, melainkan juga aspek afektif dan psikomotor siswa. Sekolah disarankan untuk selalu memberikan wadah kepada warga sekolah untuk pengembangan sumber daya yang dimiliki warga sekolah. Peneliti lain disarankan untuk mengembangkan penelitian ini dengan menggunakan variabel-variabel yang lebih beragam, sehingga permasalahan dalam dunia pendidikan dapat diminimalkan.

\section{Daftar Pustaka}

Afandi. (2013). Model-model Pembelajaran. Semarang: Sultan Agung Press.

Ahmadi, A. (2002). Psikologi Sosial, Edisi Revisi. Jakarta: Rineka Cipta.

Amalia, S. (2018). Pengaruh Metode Pembelajaran Outdoor Learning Terhadap Motivasi Dan Hasil Belajar Peserta Didik Kelas VII SMP Negeri 15 Makassar (Studi Pada Materi Pokok Interaksi Makhluk Hidup Dengan Lingkungan). Jurnal IPA Terpadu, 2(1).

Cantika, K. (1985). Pengelolaan Air Subak di Bali. Denpasar: Proyek Irigasi Bali Denpasar

Cintami \& Mukminan. (2018). Efektivitas outdoor study untuk meningkatkan hasil belajar Geografi berdasarkan locus of control di sekolah menengah atas Kota Palembang. Jurnal Ilmu Sosial, 15(2).

Devi, W. S., \& Rafvesa, F. (2018). Efektivitas Metode Outdoor study Dengan Musik Klasik Terhadap Kemampuan Menganalisis Unsur Puisi. Jurnal Pendidikan Bahasa dan Sastra Indonesia, 1(1).

Goleman, D. (2010). Emotional Intelligence (terjemahan). Jakarta: Gramedia Pustaka Utama.

Husamah. (2013). Metode-Metode Pembelajaran. Jakarta: Binarupa Aksara.

Kaiser, F.G., Oerke, B., \& Bogner, F.X. (2007). Behavior-Based Environmental Attitude: Development of An Instrument For Adolescents. Journal of Environmental Psychology 27, 242-251.

Kurnianti, D. (2020). Implementasi Metode Outdoor study Dalam Pembelajaran Ilmu Pengetahuan Alam Pada Hasil dan Motivasi Belajar Siswa Kelas IV SD Negeri Gedanganak 02 Ungaran. Jurnal Pendidikan dan Pembelajaran Ke-SD-an Elemntary School, 7(1).

Muniroh, S. (2018). Pengaruh Kepercayaan Diri Terhadap Interaksi Sosial Siswa Kelas X Smk Swasta Panca Bhakti Kubu Raya. Jurnal Pendidikan dan Pembelajaran Khatulistiwa, 7 (7).

Palmer, J., \& Neal, P. (1994). The Handbook Of Environmental Education. New York: Routledge. 
Rustam, S., \& Apik, B. S. (2015). Penerapan Metode Outdoor Studypada Pembelajaran Geografi Kelas X IPS Ma Al Bidayah Kecamatan Bandungan Kabupaten Semarang Tahun 2014/2015. Journal UNNES ISSN 2252-6684.

Sejati, A. E. (2016). Pengaruh Metode Pembelajaran Outdoor study Terhadap Kemampuan Menulis Karya Ilmiah Geografi SMA. Jurnal Pendidikan: Teori, Penelitian, dan Pengembangan, 1(2).

Sriartha, I P., \& Kertih, I W. (2019). Subak Local Wisdom as Social Studies Learning Source in Junior High School. Proceedings of the 4th Asian Education Symposium (AES 2019).

Sriartha, I P. (2017). Local Wisdom of Subak As A Model Of Character Building For Social Studies Learning In Schools. Proceedings of the 2nd International Conference on Innovative Research Across Disciplines (ICIRAD 2017).

Sudjana, N., \& Ahmad, R. (2010). Media Pengajaran. Bandung: Sinar Baru Algensindo.

Supriatna, N. (2016). Ecopedagogy: Membangun Kecerdasan Ekologis dalam Pembelajaran IPS. Bandung: PT Remaja Rosdakarya.

Sutawan, N. (1983). Keberadaan Pura pada Subak. Denpasar: Dinas Kebudayaan Propinsi Bali.

Syahyudi, Dindin. 2019. Pengaruh Gadget Terhadap Pola Interaksi Sosial Dan Komunikasi Siswa. Jurnal Kehumasan, 2(1).

Taqwan, S. H. B. (2019). Pengaruh Pembelajaran Luar Kelas (Outdoor Learning) Terhadap Kemampuan Pemecahan Masalah Siswa Kelas VII SMP Negeri 05 Seluma. Jurnal Pendidikan Matematika Raflesia, 4(1).

Witarsa, R. (2018). Pengaruhpenggunaan Gadget Terhadap Kemampuan Interaksisosial Siswa Sekolah Dasar. Jurnal Pedagogik, 6(1). 